\title{
Professional Expertise Variances among Secondary School Teachers of Bangladesh: A Study
}

\author{
Golam Mohiuddin \\ Institute of Education, Research and Training, University of Chittagong, Bangladeo
}

E-mail address: gmuddiniert@cu.ac.bd

\section{ABSTRACT}

This study aims to evaluate the levels of professional expertise well as to identify the variances based on gender and work experier expertise level is of vital importance in quality of teaching and le The study sample involved 85 teachers from various fields Chittagong, Bangladesh. The study used test with 30 questi measur teachers' professional expertise. Overall results show that the level of professio al expertise is gene ally at an average level. The result shows that there are significant variances be veen female and male teachers in terms of mastery of professional expertise. In addition, the data sh s that there s significant variance between more experienced and less experienced teachers regard naster of professional expertise. The implication is that the program, run by schools ministry ormuration, to implement to upgrade the professional expertise of teachers should con au teachers' backgrounds to make sure its effectiveness.

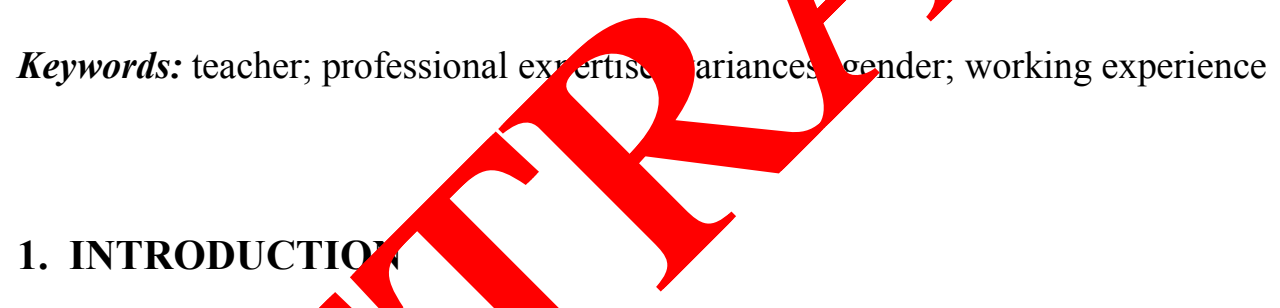

Professio al competenci as a set of knowledge and behavior which have to be possessed $g^{1}$ rved mastered professionally. Teachers are educational managers and leaders in a cla $\mathrm{om}$. Th efore teachers who are competent would be able to carry out his teachip ccess $\mathrm{v}$ aking full use of resources and materialize teaching process suco ssful Teach are expected to work systematically, consistently and creatively. Tea $g$ g requires specific knowledge and skills. Therefore, teacher education currich is aesigned to ensure that teachers are competent in content knowledge and pedagogi vills. By mastering these two main elements, teachers are able to face challenges in school. Effective teachers are a person who is able to carry out his duties and responsibilities successfully. Past studies showed that effective teachers must have broad knowledge and pedagogical skills to promote appropriate behavior (Awang, Jindal-Snape, \& Barber, 2013). Public assumes that being a teacher is an easy job. Indeed, trainee teachers also assume that the duties of a teacher are easy, manageable and could be carried out successfully. Due to this paradigm, most trainee teachers are not serious in gaining knowledge during teaching training. As a result, it brings adverse effects to the teaching profession. In reality, being a teacher is not an easy task. Teachers have to fulfill parents' expectations and they 
need to ensure that children are well-educated. Therefore, all teachers have to improve their teaching skills and content knowledge. The following elements and domains are supposed to be fulfilled by all teachers: personality, intellectual, emotion, inter-personal skills, intrapersonal skills and creativity in teaching. Teaching profession is a professional designation which requires resilience, competitiveness and good leadership skills.

These come from individual talent and abilities. Good teachers are those who are expert in teaching subject content and able to manage personnel, teaching aids and classroom effectively. Teachers who have undergone training should possess the competencies based on the theoretical knowledge, practical training and soft skills. Walker, Jeffes, Hart, Land and Kinder, (2011) have discovered that teaching implementation depends on the inve vemen d versatility of teachers in establishing an interesting and effective learning eny nment. Hz well a teacher adopts all the knowledge and involvement could be seen in the im mentati process? Teachers' dedication in carrying out the activities to inculcat teaching ten is greatly influenced by the mastery of teaching aids and in makip chang in st ents' behavior. Hence, teachers have to be sensitive towards the latest tev nent in ducation world today. Teachers have to be positive and strive to improy the stand of gacation so that the quality of teaching and learning is improved. A c ing to Su apura (1985), constant thinking and acting which is consistent and cont yous $\mathrm{ld}$ deverop a competent person who possesses knowledge, skills, values and usmattitudes yards accomplishing something. Professional career requires thinking of of the box and away from mundane routines.

This is what it means by professionalism via en and trai ing. Expertise will influence a person's work performance in carrying ant his du. social agent to the students. Professional competencies are crucial skil determine the success of a teacher in carrying his duties as professional. The fol wirg stions provide general guidelines to explore teachers' competencies:

What are the standards that $b$ ve to achiev by teachers to perform effective teaching?

* What are the skills required a

* What are the questions asked to 'students' knowledge?

Teachers' expe iso aligned in the ability to manage information, framing duty solving and active omm ation with students. Teachers also have to possess the knowledge aboh subject curn $\mathrm{am}$ and syllabus through accurate testing procedures. In other words acher hould be able to integrate the use of technology compatible with the standard techn for un ergrads in developing curriculum. Teachers have to know how to make y tech ogy and cognitive thinking process which is complex. Teachers should also o $a b$ to knov ow students learn and understand the difficulties faced by the students. Pro vion tanchers have to master of:

$>\quad$ wledge discipline as teaching resources;

$>$ tea ing content that is going to be delivered;

$>$ knowledge about undergrads' characteristics;

$>$ knowledge about the philosophy and aims of education;

$>$ mastery of teaching methods and models of teaching;

$>$ mastery of technological principles of learning; and

$>$ ability to lead and direct learning environment.

In Bangladeshi context, professional expertise refers to the mastery of education in depth which enables teachers to guide students and manage teaching activities. Competent teachers would make the effort to relate teaching content with students' background 
knowledge and provide effective learning experience through assignments, exercises and homework which are of high quality. There is a relationship between the steps taken by teachers to simplify and master teaching content with their expertise.

\section{STATEMENT OF THE PROBLEM}

This study was influenced by past studies on professionalism in teaching profession where it was found that most teachers have a lack of professionalism. Three contributing factors identified to the low level of teachers' professionalism are: (1) many teac iers wh to not fully carry out their profession; (2) low level of loyalty towards the norp and teach ethics; and (3) unsatisfactory acknowledgement of teachers towards educatinnal wledge implementing the policies to the involved parties. Past studies also re ealed that is is' integrity and accountability are often questionable. Most issues ra abo teach are regarding the school milieu and teachers' expertise in managing cla $m$ and elivering lesson. A teacher should be accountable to his duties and theref ore will har and show sense of responsibilities and subsequently will be proud ${ }_{r}$ job (Cr shank et al., 2006). There is no excuse for a teacher especially those of high ranking to be less proud of their duties and responsibilities.

The effort to improve teachers' quality actually does not stop wh-n they are assigned to their workplace. Instead, it continues for the rest o heir teachir profession. It is observed that the quality of work declines as they serve lon in the se vice. Empirical research on teachers' burnout carried out by Morrison etal. (2005) that the nonacademic routines of teachers reduce their mood to keep on lea refuse to change due to high pressure at w $\mathrm{k}, 1 \mathrm{~g}$ orkload and role conflicts. Burnout causes emotional exhaustion, physicol exhaus on, attudinal exhaustion and low feeling of accomplishment. Consequently anis fects th quality of their dedication and treatment towards their students. Theref affor s and measures have to be taken to improve the ability and quality of a teacher. con to (2009), teachers' readiness change and the optimum use of their pr ssional sk is still limited and not developing and making full use of their professional kilh still limit a that it does not improve their perseverance towards the challenges an changes are happening. Sadirman (2004) discovered that there are students who ar nothappy ano ared of teachers. Some teachers always scold their students during teach and rning activities. Some teachers have a lack of punctuality. Some of them have bee ching t s same topics repeatedly. This discourages students to be involved

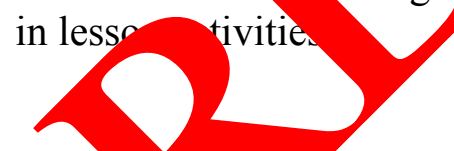

3. LI ATUKE REVIEW

Experise is the capacity to carry out teaching and learning process successfully. Capacity is also shown when an individual is successful in learning how something complex and abstract is done. Expertise is the potential skill and expertise in conducting one's roles. The basic expertise of a teacher consist of these components: time management, focus, feedback, forecast, decision making, and transfer of knowledge and culture. Gorman et al. (1997) introduced a competency model based on the study on outstanding skills and leadership qualities. This study utilized qualitative research design using individual interviews. Each individual was interviewed and results suggest the importance of emotional 
intelligence to improve competencies in handling organizational climate. Important elements identified including interpersonal skills, initiative, possessing a vision, cognitive abilities, technical skills, and high level of IQ. Five emotional intelligences investigated in that study were self-awareness, self-discipline, and high level of motivation, high level of empathy and inter-personal skills. Pillay (2005) has carried out a study on the relationship between burnout and teachers' competencies in Queensland. That study reveals that teachers' workload has a high correlation with burnout tendencies among teachers. It has negatively affected teachers' working competencies.

The research discovers that working practices and working environment aush as competitions, working nature transformation and technology could bring in pact on e wellness and competencies of teachers. According to Davies (2000), the cre process learning is crucial for a teacher. Teachers have to be creative role models for th ydents. addition, Baghart and Trull (1973) who have carried out the research on ne expert 'eve' of creative teachers have proposed several measures that could be adop by to hers, nely: the ability to accommodate to students' learning style, creating a "un ang en sonment, inculcate living skills and veracity in the students, and reduce $1 \mathrm{l}$ barrien $\mathrm{d}$ li intations in learning activities Learning Implementation Plan that y troduced pedagogical competency is the ability of teachers to carry out lean $g$ ex ience that includes the understanding of education policies, the understandin or sudents, i ioflum development, learning plans, learning implementation, benefits learning outconses, learning outcome evaluation, the realization of students' potential Gil s, et al. (2013) emphasize that the most important things to be considered in teaching practic regardi g the learning outcomes and questioning techniques used.

These will lead to effective learning mprove learning readiness and cognitive ability among students. Everything begins w the standing of the simplest to the most complex ones. Good teaching practice will pi vide students with the education in critically thinking involving the process of 1 lling il ormation, handling information, analyzing, making analogy, making in etat ins. synt resizing and evaluating. According to the criteria set forth by UNE 9 , aty andion is the combination between professional teachers with integrity dexpert Thiessen (2012) stressed that the quality of teacher should be given prior y effort to evelop effective teaching pattern.

The quality leache is measured through personal expertise, work performance, motivation, eff it and change I students' behavior. Walker, et al. (2011) suggests that teachers nee $\mathrm{o}$ imp ve their/delivery quality in order to meet the professional standards. These include workin style, teaching practice, and the use of interactive approach in commy tion. A ing quality is the product produced by the workers within a time frame whi n ince les high cialization ability among workers to be able to share working qualities. Tea $r$ s bo to avoid the decline of work performance due to burnout by sharing their worklo (Hinsnaw, Richter, and Kramer, 2010).

Mur (2006) and Arikunto (2004) proposed several criteria for competent teachers. They have nitiated specific tests in their studies which then were utilized in the current study. These tests were adapted and modified to fulfill the current research objectives. The validation of the items in the test was referred to educational experts in Indonesia. The pilot study was then carried out where Cornbrash Alpha scores indicated that the items were appropriate to be used. 


\section{OBJECTIVES OF THE STUDY}

Following are the main objectives of the study:

1) to evaluate the mastery of professional competency among high school teachers as well as to identify the differences based on gender and work experience;

2) to identify the level of professional expertise among teachers, focusing on mastery in education foundation, vision, mission and educational objectives, national educational standards;

3) to development curriculum, classroom management, usage of media and nal resources; and

4) to identify the variances concerning the mastery in professional $\mathrm{cx}_{1}$ tise amo teachers, based on gender and work experiences.

\section{METHODOLOGY OF THE STUDY}

The current study employed test to evaluate the ma ery professio al competency among teachers in Chittagong. The test of mastery of pro sonal a rtise contains 30 items which were divided into 6 constructs to evaluate ma ery in educatio cundation ( 5 items), vision, mission and educational objectives ( 5 items) hational educational standards (5 items), curriculum development moves ( 5 items), classroon nanagemen (5 items), and the ability to use media and educational resources (5 items). Samp this st dy was selected using simple random technique involving 85 teachers (-males an remales) from various fields in three secondary schools. To validate the i ce content validity of the test questions, professional experts are referred. Pilot test wo ondu, ed in one secondary school involving 85 teachers. All the items in the rtise le el and professional expertise test show high validity and reliability in whic the $\mathrm{v}$ ae of $\mathrm{CC}$ brash Alpha is 0.82 . This indicates that all items are acceptable and app ri used. Data analysis was performed using descriptive and inferenti statist including the score mean, percentage, ANOVA and MANOVA. To measy expertis el and professional expertise among teachers, this formula was used:

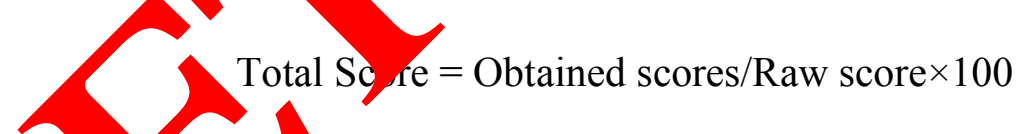

Teachers fession a expertise level is measured based on the five level mean scores. Table $y$ s the ro etation of the test scores.

able1. Interpretation of the Professional Expertise Test Scores.

\begin{tabular}{|c|c|}
\hline Score & Interpretation \\
\hline $0-54$ & Not competent \\
\hline $55-64$ & Less competent \\
\hline $65-79$ & Quite competent \\
\hline $80-89$ & Competent \\
\hline $90-100$ & Very competent \\
\hline
\end{tabular}




\section{FINDINGS AND THEIR ANALYSIS}

Overall results indicate that most teachers are quite competent (Table 1). Detailed analyses revealed that teachers are competent in two aspects that are the mastery of education foundation and the mastery of vision, mission and educational objectives.

Table 2. Mastery in professional expertise level among teachers.

\begin{tabular}{|c|c|c|c|}
\hline Professional Expertise Aspects $(n=327)$ & Mean & SD & Interpretation \\
\hline Education foundation & 83.49 & 15.12 & \\
\hline Vision, mission and educational objectives & 81.65 & 15.78 & \\
\hline National educational standards & 71.25 & & \\
\hline Curriculum development & 65.32 & & \\
\hline Classroom management & & & \\
\hline Usage of media and educational resources & & & $\begin{array}{c}\text { Less } \\
\text { Competent }\end{array}$ \\
\hline Average Mean Score & & & $\begin{array}{c}\text { Quite } \\
\text { Competent }\end{array}$ \\
\hline
\end{tabular}

The level of professional co tency ang teachers generally is satisfactory. This shows that the serving quality nong lem is a werage level. This reveals that the teachers are mastering the professiona om ancesults also indicate that teachers are less competent in classroom amgen and une of media and educational resources. Past study suggests that a te ar has to b countable of his duties which will encourage them to work hard and show high nse of responsibilities that they would be proud of their career (Cruickshank et a' 2006).

The resul of this study is consistent with the findings of a study by Mustafa M. Nur (2012) in w' she corted that the teachers' work performances also were not satisfactory. Recent research rried of by ministry of education, Bangladesh revealed that $55 \%$ of the teache still to in using lecturing method. The use of modern technology was limited. He e, it ntribute to less productive learning. Teachers have to take various efforts to imp icluding all the competency elements mentioned. Detailed analyses were carried to seek differences and commonalities between genders.

Rest. show that the professional expertise among female teachers is higher than male teachers. Table 3 shows that there are significant differences between genders with regard to the aspects of mastery of education foundation (0.028), mastery of vision, mission and education (0.000), understanding and mastery of national education standards (0.021), mastering and developing curriculum (0.010); however, in terms of the mastery of classroom management and ability to use media and education resources there is no significant difference $(0.735)$ and $(0.637)$ respectively based on gender.

These results are parallel with previous researches such as by Anderson (1990) and Bakalis (2003) which state that female teachers are more committed in the teaching profession 
compared to male teachers. Results from this study is also consistent with the research results obtained by Widoyoko (2005) who found that female teachers' professional expertise level is higher than that of the male teachers.

However, the competency in classroom management does not show any variances between male and female teachers in the research carried out by Shullman (1990). Teachers only focus on the delivery of teaching in the classroom towards academic improvement which consequently does not show obvious variances.

Table 3. Mastery of professional expertise level, by gender.

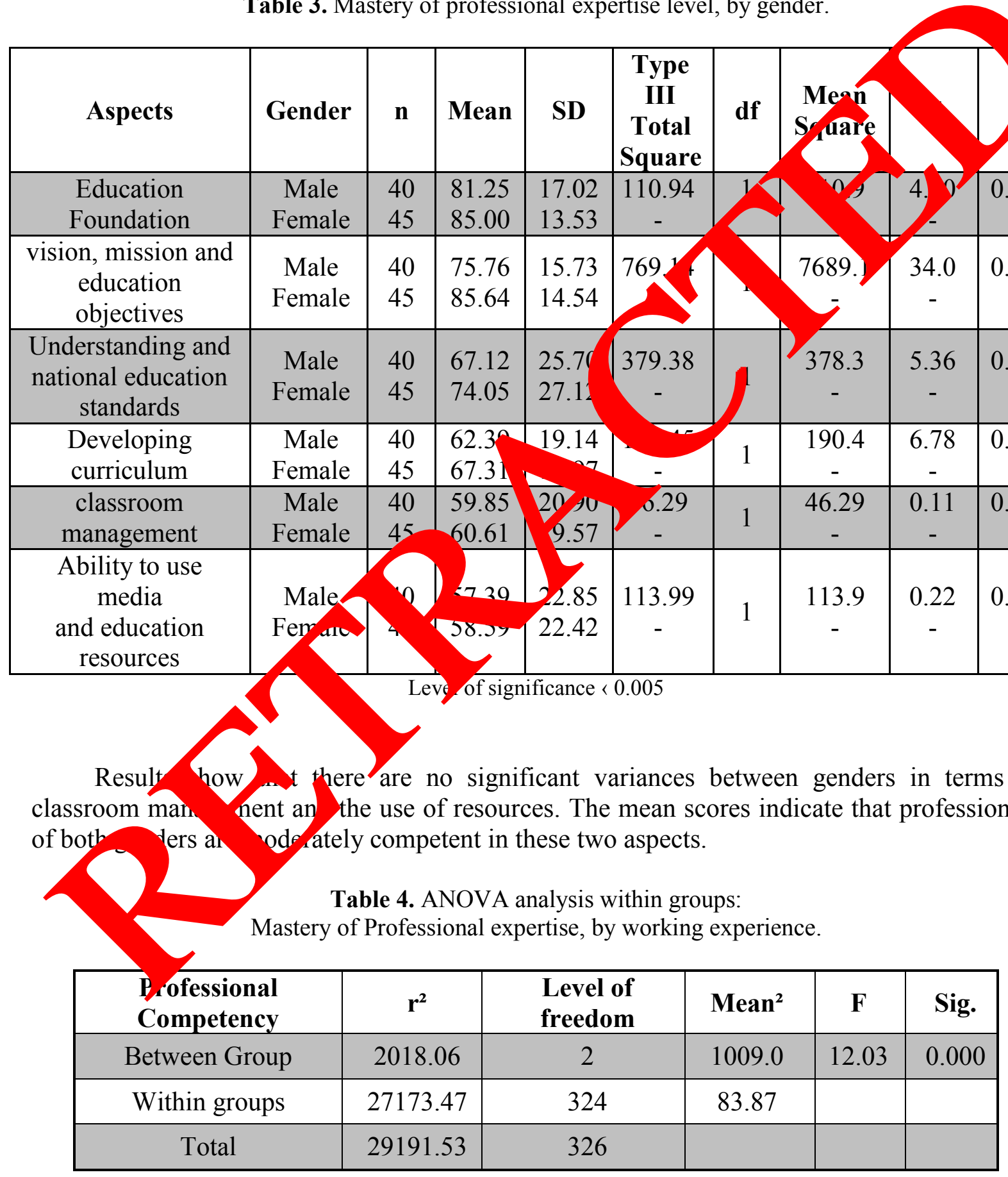


From the ANOVA analysis in table 4, it is observed that there are significant variances in terms of teachers' professional expertise between groups based on working experience. For more details of the difference, you can see in the table below.

Table 5. MANOVA analysis:

Overall teachers' professional competency level, by working experience.

\begin{tabular}{|c|c|c|c|c|}
\hline $\begin{array}{c}\text { Work } \\
\text { Experience }\end{array}$ & $\begin{array}{c}\text { Work } \\
\text { Experience }\end{array}$ & $\begin{array}{c}\text { Mean } \\
\text { Difference }\end{array}$ & Range & Sig. \\
\hline \multirow{2}{*}{$4-9$ years } & $10-15$ years & -2.28 & 1.15 & 0 \\
\cline { 2 - 5 } & $16-25$ years & $-6.66\left(^{*}\right)$ & 1.36 \\
\hline \multirow{2}{*}{$10-15$ years } & $4-9$ years & 2.28 & 1.15 \\
\cline { 2 - 5 } & $16-25$ years & $-4.38\left(^{*}\right)$ & \\
\hline \multirow{2}{*}{$16-25$ years } & 4-9 years & $6.66\left(^{*}\right)$ & 0.11 \\
\cline { 2 - 5 } & \multicolumn{2}{|c|}{$10-15$ years } & $4.38\left(^{*}\right)$ & 1.36 \\
\hline
\end{tabular}

The table 5 shows that there are significant va nces in ter $n$ s of professional expertise based on teachers' working experience. Teachers $w$ to 9 years of working experience compared to those with 10 to 15 years of e ience show no significant variance; however, compared to the teachers with 16 to 25 y trs significant variance. This means that the more experie dea ners, that is, the teachers with over sixteen years of working experien perforn d the less experienced teachers regarding the mastery of professional expert ? The efore, as Me past studies highlight (Manullang, 2002; Tillman, 2002) the more er are, the more competent in professional expertise they are. The $d$ ata shows the teachers who have 10 to 16 years of experience also show significant a vse comp 4 to the teachers with 16 to 25 years of working experience. The dat also icates that the teachers who have 16 to 25 years of working experience shoy stynificant a rence (0.003) compared to the teachers with 10 to 16 years of working ey erieng

\section{CONV USIO}

Iow that the female teachers are more competent and professional compared to the $\mathrm{m}$ teachers. The study found that the expertise of the teacher can be improved by focusing o initiative, vision in education, high intellectual training, technical and cognitive skills. Lack of teachers' professional competency can be the consequences of the policy of ministry of education as they do not provide sufficient and comprehensive in-service training for teachers. The study implication is that female teachers are more competent a professional in comparison with the male teachers. The current study revealed most teachers lack skills in managing classroom effectively. Thus, there are rooms for improvement for teachers especially in terms of classroom management and the utilization of learning resources. They must be exposed to the best practice of classroom management by visiting other schools either at national or international level. Teachers also need to attend training on the use of various 
learning resources. It is important for teachers to have creativity in teaching and carrying out their own-initiative to utilize learning resources. The current study also has an implication for policy makers as data from this study can be used as a guideline in developing short term or long term courses in order to improve educational qualities in Bangladesh. As demographic factors play important roles in developing teachers' professional expertise, any policy made by the Ministry of Education Bangladesh has to take into account demographic variables. Furthermore, it is suggested that to upgrade the expertise level and professional expertise among teachers the schools and the ministry of education should provide special in-service training for the male teachers. Due to the importance of working experience in education the teachers need to reflect on and get feedback from their own performances in th proca of teaching and learning in order to be competent and flexible enough to de with vario teaching and learning situation. Accordingly, the school heads should entrest th the tas which demand experience to share with the novice teachers and conse quently co, bute to students' academic excellence in the schools. The professional cor etenc of teac is is vital. This is because teachers with high professional expertise ar ab help th students not only to get the excellent result in the academics, but also th ey can ted stud nts how to learn in the appropriate way to become the holistic stud at Therefore, ministry of education and schools should have clear policy and lon term gram to maintain and upgrade the professional expertise of teachers.

\section{References}

[1] Abdul Razaq Ahmad, Ahamad Rah Seman A. A., Active learning through History Subject towards Racial Unity in Mayys Social Science 8(1) (2013)19-24.

[2] Anderson C. W., The rol educat on in the academic disciplines in teacher preparation dalam Woolf $\mathrm{k}(\mathrm{Ec})$, Resea $n$ perspectives on the graduate preparation of teacher. Englewood Ch N (1995).

[3] Arikunto, Manage ent teach, Humanely. Jakarta: Rineka Cipta (1990).

[4] Awang M. M. Ahm. A. R., W.hab J. L. A., Mamat N., Effective Teaching Strategies To Encourg on Learning hayiour. IOSR Journal 8(2) (2013) 35-40.

[5] Bakalis 1., Dil t teaching of paragraph cohesion. Teaching History 110 (2003) 18-26.

[6] Banghar 11, Edu Ational Planning; City Planning; Education; History; Economic s. Ma Hla, New York (1973).

[7. Crui kshank etal., Evolution of reflective teaching outcomes. The Journal of Education earom. (1) (2006) 26-32.

[8] Dav The management of learning. New York: MacGraw Hill Co. (2000).

[9] Gillies R. M., et al., Socialization and learning. Cooperative learning: The social and intellectual outcomes of learning in groups 1 (2013).

[10] Gorman et.al., Educational renewal: better teacher, better school. San Francisco: Jossey Bass (1997).

[11] Hinshaw K. J., Richter L. T., Kramer G. A., Stress, Burnout, and Renewal Activities of Dental Hygiene Education Administrators in Six US Midwestern States. Journal of dental education 74(3) (2010) 235-250. 
[12] Jamal Ma'mur AHigh Schoolsi, Seven teacher competence fun and professional. Jogjakarta: PowerBooks (2009).

[13] M. Nur Mustafa, Research Journal of Applied Science 7(9-2) (2012) 458-465.

[14] Mannullang, M., Personnel management. Jakarta: Ghalia Indonesian (2002).

[15] Morrison, D. M., Mohaski, K., \& Cotter, K., Instructional quality indicators research foundations. Cambridge, MA: Connecticut (2005).

[16] Mulyasa, Become professional teachers: Create learning creative and cuddly. Bandung: Teens Rosdakarya (2006).

[17] Pillay et al., Well-Being, Burnout and Competence: Implication For Teg Austral Journal of Teacher Education (2005).

[18] Sardiman, Learn and learning. Jakarta: Rajawali Press (2004).

[19] Shullman L. S., Knowledge and teaching: Foundations of en the ne reform. Harvard educational review, 57(1) (1990)1-22.

[20] Sutadiputra, Various Teachers Problems. Bandung: A gkas 1985).

[21] Thiessen D., Classroom-based teacher. Early pousional a sopment for teachers
(2012)317.

[22] Tillman, Living values: late educational prog n educator Training Guide. USA: HC. Inc (2002).

[23] Walker M., Jeffes J., Hart R., Lord P der K., Making the links between teachers' professional standards, induction, pery management and continuing professional development 75 (2011).

[24] Widyoko, Competence of leach 's teach gg IPS SMA Kabupaten Purworejo. Studies Pensyarah Muda. Dirjer did on Tingog Indonesian (2005).

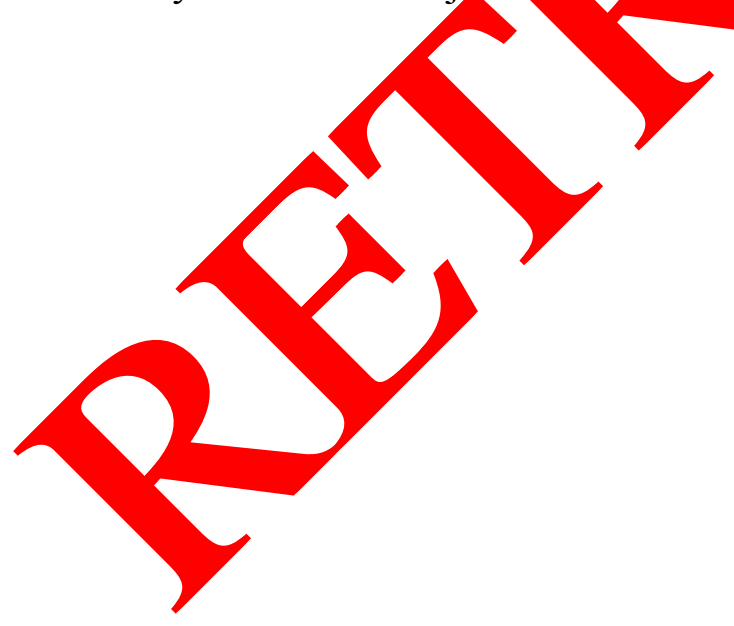

